\title{
Vietnam in the Later Family: Self-reported Symptoms and Interpretations of Posttraumatic Stress
}

\author{
Terri Kovach* + \\ Monroe County Community College
}

* Please address correspondence to Dr. Terri Kovach, Campbell Learning Resources Center, Monroe County Community College, Monroe, MI 48161. E-mail: tkovach@monroeccc.edu.

+ Author's Note: Preliminary analysis for this paper was conducted in preparation for a conference presentation titled, "A Folding Chair Falls on the Church Basement Floor: PTSD in the Community 40 Years after Vietnam," given at the Association for Applied and Clinical Sociology, Ypsilanti, Michigan, in October 2007.

\begin{abstract}
The influence of combat exposure in the Vietnam War continues into later family life as this veteran cohort ages and family structure expands. The author utilizes qualitative, phenomenological analysis to examine the meaning of PTSD symptoms such as re-experiencing, avoidance/numbing, arousal, and social impairment and how they influence family function. Veterans describe how combat trauma shaped experiences of nightmares, callousness, triggers, anger, startling, control, and substance abuse and interpret those behaviors as damaging or enhancing their family relationships and friendships. This project has implications for veterans of the Gulf War and the current wars in the Middle East as well as for their families.
\end{abstract}

Keywords: Vietnam War, veterans, combat, Posttraumatic stress disorder, family, phenomenology

66I just didn't fit in." This comment is typical of Vietnam War combat veterans who returned home "to sit in my mother's kitchen," often within days of firing at enemy soldiers (Kovach, 2006). This research reports on the phenomenological analysis of qualitative interviews with 10 Vietnam War infantry combat veterans who live in Ohio and Michigan. These are no longer the just-home soldiers, young husbands and fathers of early Vietnam veteran research. Rather, they are aging husbands, divorced men, and grandfathers who are nearing the ends of their 
careers or have already retired. For the purposes of this article, the later family is conceptualized as advanced in time/age and in structural complexity. Research has demonstrated that most veterans reentered civilian life successfully, even in the face of posttraumatic stress disorder (PTSD) symptoms (Kulka et al., 1990a, 1990b). Nonetheless, these symptoms remain; they may fade over time, but they do not disappear. This research asks: How do Vietnam veterans understand their combat experiences and the sometimes-disabling PTSD symptoms that they attribute to Vietnam? This research also describes the efforts of veterans to interpret symptoms and their influence on everyday life in the later family.

PTSD has been the primary frame for research on Vietnam veterans, providing a complex understanding of the personal mental health and social consequences of combat. The diagnosis was first outlined by the American Psychiatric Association in the 1980 edition of Diagnostic and Statistical Manual (DSM), revised in 1987, 1994, 2000, and most recently with the 2013 edition of the DSM-5 (American Psychiatric Association [APA], 2012, 2013) in response to research and clinical practice. Community studies reveal an $8 \%$ lifetime prevalence rate for PTSD in the U.S. adult population. With a range of severity, this disorder is marked by specific criteria:

1. exposure to a traumatic event (in this case, combat violence during the Vietnam War) and resultant feelings of intense fear, helplessness, or horror (this last descriptor was removed in the 2013 edition);

2. re-experiencing by intrusive thoughts, memories, nightmares, feelings or actions of reliving the event ("flashbacks"), or intense emotional reaction to reminders;

3. avoidance behaviors related to reminders or cues, and numbing of affect or detachment;

4. negative changes in cognition and mood (some of these elements were included in \#3 above in the 2000 edition);

5. increased arousal that may include sleep disruption, anger, hypervigilance, difficulty of concentration, or exaggerated startling; 6. duration of symptoms 2, 3, 4, and 5 of more than one month; and 7. significant distress or impairment of social, occupational, or other important functions (APA, 2000, 2013).

The diagnostic criteria are specific about number of symptoms, in what combination, and duration. PTSD interferes with intimate family relationships and social functioning in the wider world of work and the community.

Figures on living Vietnam-era and Vietnam-theater veterans are confusing because of differences in parameters: reports include the spans of 1961-1975, 1964-1973, 1964-1975, and 1965-1973 (Brady, 2011; Committee to Review, 1994, p. 80). Additionally, Vietnam theater is defined as Vietnam, Laos, Cambodia, and adjacent waters, but some reports include Thailand. Census Bureau reports estimate roughly 7.5 million living Vietnam era and 3.5 million living Vietnam theater veterans, with an age range of mid-fifties to late seventies (Brady, 2011; U.S. Census, 2011). The literature related to Vietnam veterans is 
robust, making it impossible to provide a comprehensive review in this paper. Major topics outlined below include determiners of military service, stress reactions, mitigation of stress, and the influence on veterans' families.

\section{Who Fought in Vietnam?}

Researchers disagree on the social characteristics that influenced who fought in Vietnam. King and King (1991) reviewed the literature that suggests that socioeconomic status influenced both military service and combat deployment. Minorities and men from lower socioeconomic levels were more likely to be in the Marines and the Army, and thus more likely to engage in ground battle. Those with lower academic skills were more likely to be combat soldiers. Blacks were nearly 1.5 times more likely than Whites to experience heavy combat. Gimbel and Booth (1996) suggested aptitude test scores, age, volunteering, aggressiveness, and stress management skills were more reliable predictors of combat-arms assignments than race, however.

\section{Combat \& Stress}

Nearly a third of the hundreds of thousands of heavy combat veterans from the Vietnam War suffered from severe PTSD (King \& King, 1991). Vietnam veterans were particularly vulnerable to stress symptoms because of the length of the war, deployment patterns, guerilla tactics, the perceived lack of purpose, and the increasing unpopularity of the war, often resulting in veterans being treated with contempt. Shay (1994) stated, "Untreated war trauma can leave men as speechless as victims of prolonged political torture" (p. xxii). Shay, as did Linderman (1997), described the element of luck in the soldiers' world. This is a paradoxical luck: Veterans spoke frequently of the uncanny luck and vagaries of combat, but often considered those who died in Vietnam to be the "lucky" ones. This likely reflects the depth of suffering for those who survive combat only to be troubled by severe PTSD.

The earliest studies on combat in Vietnam were published in 1972, three years before the end of the war. Kaylor, King, and King (1987) conducted a meta-analysis of 67 studies of Vietnam War veterans conducted between 1972 and 1985, concluding that Vietnam-theater veterans demonstrated higher levels of socio-psychological illness than Vietnam-era veterans and non-veterans. The researchers also argued for a "Vietnam effect," suggesting that even non-combat service in Vietnam had a detrimental effect on later life.

One of the earliest large-scale studies was Legacies of Vietnam (Egendorf, Kadushin, Laufer, Rothbert, \& Sloan, 1981). Vietnam theater veterans had not achieved the educational levels or employment status of their Vietnam-era or civilian contemporaries and had higher rates of substance abuse, trouble with the law, illness, and stress-related symptoms. Stress reactions appeared to be exacerbated by low educational levels, unemployment, and minority status, while social support from wives or veteran friends mitigated reactions. The small proportions (5-10\%) of well-adjusted veterans were those who had successfully "worked through" psychological issues. Veterans from small cities had lesser symptoms of emotional problems. 
Laufer, Gallops, and Frey-Wouters (1984) argued that war trauma included combat exposure, witnessing abusive violence, and participation in abusive violence. The Centers for Disease Control Vietnam Experience Study (1988) concluded that PTSD was associated with patterns of maladjustment and comorbidity. Resnick, Foy, Donahue, and Miller's (1989) study (cited in Barret et al., 1996) concluded that childhood behavior problems and combat experience independently predicted adult antisocial problems. Barret et al. (1996) showed a prevalence of antisocial personality disorder of $11 \%$, compared to $3 \%$ in men in the broader population. Those exposed to high or very high levels of combat were twice as likely to report problems with employment and partner/non-partner violence, even after controlling for childhood experience.

Results of the National Vietnam Veterans Readjustment Study (NVVRS) (Kulka et al., 1990a, 1990b) showed 31\% of male Vietnam theater veterans suffered from PTSD at some period following the war, with $15.2 \%$ at the time of the study and compared to a civilian rate of $1.2 \%$. Despite the large numbers of veterans with continuing psychosocial problems related to PTSD, the majority successfully reentered civilian life with few problems. Later analysis of the NVVRS 1990 dataset described a stronger relationship between combat exposure and PTSD severity, but lower overall rates: $22.5 \%$ war-related onset and $12.2 \%$ at the time of data collection (Dohrenwend et al., 2006). Martz, Bodner, and Livney (2009) used the NVVRS data to determine the effect of problem-solving coping on psychosocial adaptation, describing a positive effect for those with less severe disabilities, but a negative effect for veterans with more severe disabilities.

A small-scale study of 103 male Vietnam veterans (Kovach, 2006) found that specific types of combat exposure predicted self-reported PTSD symptoms. Close combat experiences influenced the presence of nightmares or intrusive thoughts, not thinking or avoidance behaviors, and numbness or detachment. Being wounded and treated or hospitalized influenced symptoms of guardedness, watchfulness, or startling behaviors. Nearly one-third of the community-dwelling veterans in this study satisfied the screening criteria for PTSD (Kovach, 2006).

\section{Mitigation of Stress}

Some elements of the homecoming experience are more likely than others to predict PTSD. Johnson et al. (1997) suggested that negative personal interaction, resentment, and shame within the first six months of homecoming were associated with the disorder. The homecoming experience was the strongest predictor of PTSD, followed by combat exposure, pre-military factors, and postmilitary stress. Some of the homecoming stress may have been engendered by PTSD symptoms that were already evident in the returning veteran.

Researchers in psychology have examined combat veterans in relation to identity formation, quality of life, and resilience. Silverstein (1996) suggested that maladaptive defense behaviors related to male ego development result from PTSD. These result in a greater likelihood of problems with marriage, employment, and the law. Zatzick, Marmar, and Weiss (1997) described PTSD as the "core problem" of veterans being treated for depression, substance abuse, anxiety disorders, or other medical conditions. In a study of veterans aged 44 to 
91 (Aldwin, Levenson, \& Spiro, 1994), life-long negative effects from combat were observed, but the perception of positive benefits mitigated symptoms of PTSD. "They felt if they could cope with war, they could cope with anything" (Aldwin et al., 1994, p. 42). Elder and Clipp (1989) examined WWII and Korean War veterans, finding that heavy combat veterans with stress-related symptoms still exhibited greater levels of resilience and less helplessness compared to nonheavy combat veterans. Gulf War veterans who actively attempt to cope by analyzing and making efforts to solve problems, seek out guidance and support, and positively reappraise a stressful situation report lower levels of short-term and long-term symptoms of stress (Sharkansky et al., 2000). Williams, Johnson, Heiss, and Rose (2010) reported higher levels of trait anger in combat veterans over non-combat and non-veterans of both Korean and Vietnam wars, arguing that this propensity toward anger may lead to lower health. Based on this literature, it is clear that combat veterans have unique experiences of PTSD when compared to non-combat veterans, but they also may have distinct coping skills honed in combat.

\section{Combat \& Family Relationships}

Families are influenced by parents with combat experience in complex ways. Hendrix and Anelli (1993) reiterated earlier research that levels of combat exposure influence the psychological impact of veterans' war experiences. There is partial support that the psychological impact of combat subsequently influences family function and satisfaction, but researchers have not found a direct effect of the levels of combat on family function and satisfaction. Dansby and Marinelli (1999) suggested that adolescent children of Vietnam veterans demonstrate no significant difference on social and personal adjustment or personality development, but have poorer attitudes toward school, more negative attitudes toward their fathers, higher rates of depression, tension, apprehension, and anxiety, and more behavior problems. Women in long-term relationships with veterans with PTSD often exhibited the same symptoms, a phenomenon called "secondary traumatization," (Nelson \& Wright, 1996). A study of 260 malefemale partner dyads selected from the NVVRS suggested that male-perpetrated violence was associated with the wife's level of psychological distress. Children's behavior problems were linked to the violence, but only through the mother's psychological distress (Street, King, \& King, 2003). Female Vietnam veterans and their aggression (both physical and psychological) towards intimate partners influenced their children's behavior problems, but psychological distress in the parents did not (Watkins, Taft, Hebenstreit, King, \& King, 2008).

Specific elements of veterans' behaviors and PTSD symptoms influence family dynamics in different ways. Hendrix, Erdmann, and Briggs (1998) reported that veterans' self-reported avoidance symptoms had direct effect on spousal ratings of communication and indirect effect on parental satisfaction. Arousal symptoms had direct effects on spousal ratings of cohesion, adaptability, and marital satisfaction, with indirect effects on both parental and marital satisfaction. More recent analysis of the 1990 NVVRS by Van Winkle and Safer (2011) recommends that mental health assessments of combat veterans should 
include efforts to elicit specific behaviors of actual participation in killing over the presumedly less-stressful witnessing of killing or trauma. There is a weak relationship between active participation in killing and spousal reports of physical abuse in the previous year. A 14-year follow-up study of some 1400 communitydwelling Vietnam veterans showed that $10 \%$ experienced severe PTSD symptoms (Koenen, Stellman, Sommer, \& Stellman, 2008). Symptoms were associated with worse family relationships, lower measures of life satisfaction and happiness, and higher levels of smoking, mental health service use, and non-specific health complaints.

A comprehensive overview of research on functional impairment as a consequence of PTSD is offered by Rodriguez, Holowka, and Marx (2012). Concentrating primarily on materials published since 2008, the authors outline five specific areas of impairment: intimate relationships, friendships and socializing, parenting, work and academic performance, and financial problems and homelessness. As a complement to the VA/DOD Clinical Practice Guideline for Management of Post-Traumatic Stress (Management of Post-Traumatic Stress Working Group, 2010), Rodriguez et al. (2012) suggest that clinicians use patient self-reports combined with "collateral data" from family, friends, and coworkers for a complete functional assessment of possible PTSD clients.

Research on Vietnam veterans has framed some of the study of contemporary veterans and their families. A study of over 20,000 married soldiers returning from deployment reported that $18 \%$ experienced interpersonal conflicts with spouses, family members, friends, and coworkers (Gibbs, ClintonSherrod, \& Johnson, 2012). Additionally, race/ethnicity, pay grade, lower health status before deployment, two or more symptoms of PTSD, at least one indicator of depression, alcohol consumption, and concern over alcohol abuse were each independently associated with interpersonal conflict.

A very large body of research relates to combat exposure and its influence on PTSD, and the influence of PTSD on family function. This research project will address how Vietnam veterans recall and interpret their PTSD symptoms and will discuss how veterans view the influence of PTSD symptoms on family functioning.

\section{Methods}

The well-documented prevalence of PTSD symptoms and statistical relationships between symptoms and family functioning prompts the research questions at the foundation of this article. How do Vietnam combat veterans understand and interpret their continued PTSD symptoms? How do they think about and discuss PTSD symptoms in relation to their families? What does PTSD in the later family look like? These questions satisfy Creswell's (2003) standards for using qualitative methods and a phenomenological approach specifically. The intent is to understand the meaning of the experience rather than to further examine population rates or statistical influences exhaustively studied elsewhere. A rich description, as found in this study, will lead to a more comprehensive understanding of the PTSD symptom realities of these veterans and their families in their natural settings, and allows readers to hear the voices of the veterans as 
they describe their lives.

Ten respondents were recruited by convenience and snowball sampling techniques using professional and community contacts in Ohio and Michigan in 2005 and 2006. Only infantry combat veterans were recruited, i.e., those most likely to have personal and intense combat experience. Initial contacts were made through personal conversations and phone calls, some of which were facilitated by an "insider" intermediary. There is self-selection bias in this recruitment approach, but this strategy insured the approachability and accessibility of the veterans. Four men who had originally expressed interest or were recommended were not successfully recruited. Respondents were either Marine Corps or Army veterans; each had been stationed in Vietnam. The researcher is a female member of the same age cohort, with experience as a qualitative investigator at a Veterans Affairs medical facility. The 18 interview questions were structured around life before the military, memories, wounding, faith, admiration, coming home, family and intimate relationships, friendships, work, health, and experience as a veteran. There were no specific questions about PTSD; thus, data analyzed in this article were unprompted. Five interviews took place in personal homes, one in a veteran's workplace, two in campus offices, and two in restaurants frequented by the veteran. The home and workplace interviews offered chances to look at family pictures, combat memorabilia, and evidence of community activities (some veteran-related). Initial analysis resulted in the development of a disjunction model between pre-combat expectations and post-combat realities, and this model is discussed elsewhere (Kovach, 2006).

The goal of this portion of the project was to explore the phenomenon of PTSD symptoms and the meanings or interpretations given to them by veterans as they influenced later family life. Elements of combat exposure and PTSD symptoms from the interviews were organized into a rough temporal framework: initial effects (wounding, fear, callousness, numbness, quickness of thought), early responses (alcohol/drugs, violence, anger/hate), residual effects (never forget, reliving, triggers, startling/hypersensitivity, nightmares, worry about "losing it," control, isolation) and recovery (choices, helping, friendships). One theme, failure to understand, was left in its own category. This was a very strong theme in three of the interviews and described the early and ongoing failure of families and friends to understand what the veteran had been through and might still be dealing with. While this element was related to the symptoms of anger/hate and isolation, it is a view of another person's behavior and thought, rather than the veteran himself and may warrant a separate analysis. Seventeen elements were then reorganized into the PTSD diagnostic scheme for clarity of description and analysis:

- Exposure:fear, wounding

- Re-experiencing: never forget, reliving, nightmares

- Avoidance / Numbing: worry about "losing it," callousness/numbing, triggers

- Arousal: anger/hate, control, startling/hypersensitivity

- Significant distress or impairment: alcohol/drugs, violence, isolation, 


\section{helping, friendships.}

Since these men were interviewed decades after the end of the war and they discussed their ongoing symptoms, the diagnostic criterion of PTSD symptoms with duration of more than one month is assumed. Three themes (quickness of thought, failure to understand, and choices) were outside the scope of this analysis and removed. Excerpts are verbatim with occasional ellipses. All names are pseudonyms.

\section{Results}

The age range of the 10 respondents is 53-65, with an average age of 57.7 years. Their ages while in Vietnam ranged from 18-28. Four are in first marriages (three are long-standing, one very recent), four are in second marriages, one is in his fifth marriage, one is divorced. Three men are African-American, seven are Caucasian. This section will examine five specific PTSD diagnostic criteria using the interpretations and meanings of the veterans themselves.

\section{PTSD: Trauma Exposure}

Initial recruitment and selection of the respondents was made specifically because they had high levels of combat exposure; each had been trained in infantry combat and had participated in ground fighting. All had discharged weapons, been fired upon, seen dead and wounded, and helped wounded soldiers. One had handled dead soldiers and body bags as his first assignment in Vietnam. Most had received some physical injury, even if minor. One respondent suffered a severe shoulder/chest gunshot wound that resulted in long-term physical impairment. Another's injury had been so severe that he had been left for dead. Except for those whose deployments were cut short by severe injury and hospitalization, all spent at least one year in Vietnam. One had served two tours and left the military rather than serve a third tour. The recollections involved descriptions of injuries such as legs blown off by explosions, decapitation, gunshot wounds, and disembowelment. "It was not a good mission" was the understated description of a particularly bloody battle. Few veterans spoke in detail about physical wounds; the interviews were not intended to explore the specifics of combat mayhem or gore. When asked whether he had been injured, Frank described how he had a small shrapnel wound, picked out in the field. "Other than that, I didn't get wounded, but I was emotionally wounded."

The element of fear saturated some sections of the interviews. Veterans described how fearing the fear was worse than fearing death. Death comes quickly, in a snap, but the fear ahead of death, the thinking ahead of death "makes it really crazy." Frank said,

"It tore me apart. And, literally, because I began to eat, you know, chew all my fingers to bleed at the same time. Chewing them up, all my cuticles, and skin. I still do it to this day."

Roger said that he was so afraid "your body implodes upon itself." The invasiveness and overwhelming nature of fear was also described as the hardest 
thing about Vietnam for Clark: "... and it has a tendency to crawl into you and embed itself, to where your trust is not as outgoing as it normally would be..." Clark explained both the fear of the veteran and fear for the veteran that family members later experienced. Two other respondents finally suggested fear related to God and guilt: "thou shalt not kill."

\section{PTSD: Re-experiencing}

Intrusive thoughts is one of the diagnostic criteria for PTSD. Three of the veterans recalled particularly gruesome injuries sustained by other soldiers. George described how a tree shielded him from an explosion that killed one of his men and wounded all the others near him.

Like here's a tree, he went in on that side and I went in on this side. He stepped on a bouncing betty [landmine] and blew him completely apart while all I could do was hear something going over my head. And it was his head...I remember that all of the time.

Roger described the gut-shot to a soldier who remained conscious, asking "Is it bad?" while Roger was trying to push the soldier's intestines back into his body, along with the dirt and leaves surrounding them. Roger described this as "stuff you never forget it."

It's just in you... God, I wish, I wish I could give it to you. I wouldn't give it to nobody 'cause I'm too humane to give something like that to somebody, but I wish though I could throw it up there in the air.

These same veterans also mention the nightmares that are included in the re-experiencing element of PTSD. Roger described a scene of a young thief who was shot by the communists, then run over in traffic, and whose crushed body was pillaged for valuables by street children. "I was having nightmares. I used to see that guy getting his head smashed. Oh, man, I still see things like that, you know." A fourth veteran, Jack, told the story of his granddaughter who had witnessed a car accident which injured a young girl. After seeing her drawings of the scene, in which she showed the broken body of a girl, Jack was grateful that she had been able to get counseling. He was visibly alarmed during the interview when he described how she would have had nightmares if she had not gotten help, suggesting his own experiences with nightmares.

In contrast, Jack's story of a theft at his home was filled with laughter. Hearing a sound in the night, he went to investigate - nude, with his .22-rifle. "I'm laying up against the house like a combat soldier. I still don't remember I have no clothes on." [He described how he emptied his rifle toward the retreating car, hitting a headlight.] "And by this time, zoom!!! the sheriff's car, and here I am standing, and now I realize I'm naked. I got this weapon. I just let loose. They're going to put me in jail.”

Jack said that he worried about whether he had injured anyone. He laughed as he wrapped up his story.

"They never did find the guy... but that's the way I am, and I constantly 
hear things, look at things, watch at night. I'm always checking. Always checking, probably always will. It never will stop."

Most of these re-experiencing responses happen in a family context. Nightmares occur while sleeping with a wife or partner. A grandfather looks upon his granddaughter and worries that she will suffer the same nightmares that mark his sleep. It is the wife who calls 911 while her husband races to shoot at intruders. For families of some Vietnam veterans, this is just another day with Dad or Grandpa, another day of ongoing stress in the family. The veterans in this study ultimately find that everyday family contexts continually trigger fears and memories, and they are forced to re-experience war, even 40 years later.

\section{PTSD: Avoidance and Numbing}

Veterans recognize that there are things that remind them of Vietnam and some go out of their way to avoid these triggers. Two respondents say they no longer hunt, even if it means isolation from male friendships. Frank no longer fishes for sport and is often chided by his friends for not keeping large fish.

After Vietnam, I won't hunt no more. I won't kill nothing unless I am going to eat it. Cause I ain't gonna eat it and I ain't gonna kill it. I saw too much, too much. When you see that a person dies, just like animals, you know, you don't die no different. You don't want to hunt no more.

These veterans acknowledge their past uneasiness with people of Asian descent. Some of that continues. George, who had described the decapitation earlier and has a diagnosis of PTSD, went on to say that he always remembers those things. He was recently invited by a veteran-lead group to return to Southeast Asia. He described his refusal by repeatedly saying during the interview "I didn't lose anything in Vietnam." He will not go to Vietnam again, offering that while it may be therapeutic for some, in his case, "You never know how you're going to react to when you see NVA [North Vietnamese Army]....it doesn't bother me here, as much as it would bother me over there." Earl, who grew up in a military family and attended a military high school, described his early and successful efforts to be unbiased toward Asians. He also defends those avoidance behaviors in others, calling them "safeguards" for veterans with traumatic memories.

Numbing of affect or detachment was described by most interviewees. This was usually associated with descriptions of fear in combat, outlined earlier. For instance, Roger explained, "I mean you get so afraid, you're past being afraid. It's like you become numb." When asked about his later life, he said that he did not have hope or as much fantasy as other people. Another veteran, Ted, said that his emotions had been "turned off." He went on to say that he had no love, no respect - those emotions were gone. He was numb in his friendships and never trusted people. However, he was explicit in questioning whether this was a result of his Vietnam experiences or his life before Vietnam, when he was raised in an abusive family. He recalls a litany of pain in his life, beginning with Vietnam and continuing with the pain of death, failure, deaths of friends, a failed marriage, 
cancer in his family, and crime in his family. "The pain that is around me is what motivates me to keep going. Yeah, I remember that like it was yesterday, and it kind of numbs my joy." Ted's response has been to avoid emotional intimacy in personal relationships.

Jack's view was that the Christmas that he spent "alone" in Vietnam, just before the birth of his first child back home and his birthday a few weeks later, was at the root of life-long numbness and sadness. He relates this to anger and hate because he was not being able to enjoy a few hours of relaxation, even with pictures of his new daughter.

And I never, I never was happy after that, I don't think....I've had a million happy moments, babies born, married to my, my wedding to my present wife, and I could just go on and on, but at that time, I was not a happy man.

He also describes his wife's difficulty in accepting this long-term "grief" or "sorrowful" memory. Jack's story allows us to see how difficult personal relationships can be against the Vietnam backdrop and the subsequent numbness that veterans experience.

Interestingly, some veterans describe this numbness as an asset that allows them to stay in control in an emergency. Two of the respondents who finished careers in law enforcement found that their "callousness" was helpful in remaining calm and sticking to business at a bloody crime scene or accident. After a plane crash, Steve recalled that many first responders were very troubled by the task of recovering body parts.

I had to step back and say, "What's wrong with these people? Why do they have to, they need debriefing?"...And then you have to, I think, understand that they've not had the same experiences. And this is new [for them].

Ted's description of his numbness and pain, outlined above, included his effectiveness as a gun-carrying "enforcer" for his girlfriend, who was a drug dealer. He also described a "20-year, long, numb, relationship" with her. While avoidance appears to keep these veterans in a state of emotional stability, the numbness and emotional distancing associated with this symptom cluster can prove challenging for family relationships. The emotional closeness that is the core of successful family function and intimacy appears to be only partially available to some of these veterans. This is the case no matter how many years have passed.

\section{PTSD: Arousal}

Seven of the ten respondents described life-long behaviors that would fall under this symptom set: Stories of anger, hypervigilance, and startling reactions were common. Angry outbursts marked many personal and professional relationships, particularly in the early days and years. Joe said, "I was a Vietnam vet and hostility was what I was thriving on." Earl described a conversation with his father, "You're gone, and I had such anger and hate in me. You lose a sense 
of humanity and turn into a monster." Anger would keep people-family, friends, and co-workers - away. Roger described his threatening demeanor further,

When I talk to people generally you look them into the eyes and stuff. I can go there. I have a way about me sometimes where I can actually get so upset, and I can look at you, and I guess what you may be able to see in my eyes is your death.

Veterans in this sample were clear that anger had damaged family relationships, some beyond repair.

Startling reactions are sometimes a source of humor, but can be dangerous. Reactions to backfiring cars, sudden sounds, and children dropping things in the house warranted matter-of-fact descriptions. Jack described his friends' amusement when he startled at a folding chair falling at a recent church function:

It'll always be there. Sudden sounds scare me to death still today...I don't recognize it as a normal chair falling over until after the fact, and it's like seconds later that it's okay not to crawl under the table.

Similarly, Arthur, who was left for dead during the Tet Offensive, said that he warned people throughout his life not to come up and grab ahold of him because it might provoke a violent reaction: "It was a survival technique."

A frequent response to arousal symptoms was effort toward self-control. Frank said that he knew how to follow rules, knew how to follow his father's dictum that he could stop doing anything if he just put his mind to it. Initially this gave Frank a kind of permission: that he could drink or use drugs and "not get a habit." Eventually, after decades of substance abuse, he has settled into a routine of "making meetings" of Alcoholics Anonymous (AA) and knows that his slip back into "the habit" or "trouble" begins with missing those meetings. He makes no promises or resolutions to himself since failure to meet those promises will begin a slide into guilt and drug use. In contrast, "just stopping" was a strategy that worked for Roger after figuring out that the hangovers were making him sick at work.

Controlling others and controlling their surroundings were also responses to unpredictable environments. Jack spoke of being mean, harsh, and regimented toward his family. Roger and Jack, both with large families, described outbursts and anxiety when they cannot find household items that are not in their proper places. Both said that knowing where things were-equipment, weapons, supplies, other soldiers - was an element of survival in Vietnam. At the same time, half of the respondents described their capacity to stay calm and plan out solutions while others became excited as a positive part of their controlling behavior. This is redolent of some of the descriptions of numbing and detachment and being able to stay calm in an emergency, described earlier under avoidance and numbing. Jack, who had shot at thieves in the middle of the night, described his controlling behavior to keep his family safe. He performs "guard duty every night": checking doors, windows, and sounds while the rest of his family sleeps. 
Veterans described keeping themselves and their households under control as a way to keep their arousal symptoms of anger and hypersensitivity in check.

These arousal symptoms and concomitant efforts toward control continue long after Vietnam and last long into marriages and families. Veterans in this sample describe wary wives who avoid touching them suddenly and children who, now grown with their own families, remain distant from their fathers. Jack recounted a conversation with an adult daughter who said she had to move out of the house sooner than she wanted to because she could no longer face his anger. Laughing, Jack said, "At that time I thought I was pretty much a mild old man." It was some 10 years after her departure, 30 years after he had returned from Vietnam, that they were able to have a conversation about how his PTSD symptoms had affected her.

\section{PTSD: Significant Distress or Impairment in Social Function}

Substance abuse is not itself a symptom of PTSD, but combat veterans have higher rates of substance abuse and the respondents included it in descriptions of post-combat impairment. For four of the respondents, conversations about problems with family and work relationships began with descriptions of anger and ended with stories of substance abuse. Some used alcohol/drugs to escape from fear in Vietnam and from anger when they returned to the states. Frank said that his wife and daughter lived the life of addicts, deprived of food, clothing, money, and a stable life because of his need to pursue his drug habit. He occasionally used his young daughter in a stroller to steal items from stores to sell for drugs. He was visibly agitated when he recalled his realization that his daughter had watched him and friends in the bathroom, with needles stuck in their arms. Clark told how he found "refuge" in the bottle. "It was my escape from some of the devils that I was, that were living within me." Two of the men were explicit about their families' responses to this behavior, and how it was their families' pressure that steered them into recovery. Frank described how the last of his brothers finally "cut me off," forcing him to realize just how much trouble he was in. Clark's wife and high-school-aged children pushed hard: "We got to, got to the point where they held court on me. 'Which is it going to be? Do you want us or do you want the bottle, because the bottle is beating you." Long-divorced and the only single respondent, Frank now sees his daughter and granddaughter regularly, even as he continues to make his AA meetings. For Clark, it had only been about a decade since the confrontation with his wife and children. The children were in their twenties at the time of the interview and he described them with fondness and pride.

The combination of anger, substance abuse, startling behaviors, and control issues sometimes resulted in violence toward family members and coworkers. Respondents described physical or psychological conflicts between themselves and others. George's wife insisted that he get help after he started "smacking the kids around." Near the end of their 7-year marriage, she "brought that rage out" and he nearly choked her to death. "And if the kids hadn't said anything to me, hollered at me, said, 'Dad, don't,' she would have been dead." A co-worker made him so angry that George "hung him up" on a wall by his throat. 
Frank (who said that others could see their death in his face) had an explosive anger that led his wife to steer him to treatment, but he also said it kept people from confronting him at work. It did not keep him from being dismissed from jobs, however. Jack described his children's questions when they got old enough to "fight back with words"; they would ask, "Why are you so mean?" Earl is in his fifth marriage and used marital conflict (arguments over underwear on the floor or toiletries out of place), not physical conflict, as an example of how the war had changed him.

...he has none of those values, and she tries to change the guy, and if the guy doesn't change, then there's conflict. Well, that is battle, and whenever I think anybody goes into war or conflict of bullets flying, I say kill them. Undoubtedly it [war] changes you.

Seven of the ten respondents described family isolation or estrangement as a result of their behaviors. George never returned to therapy because he would not stay away from other veterans as his therapist had suggested, but has not seen his children in over 20 years. An offer through a family member to meet with them has gone unanswered. He still rarely mixes with non-veterans. Frank, the only divorced and still-single respondent, in and out of treatment programs for substance abuse, describes himself as "tired of relationships...I'm the kind of guy who just needs to be by himself." Jack says that he still does not get close to anyone. Earl describes his "superficial" conversations with his son. Roger says that his family still treats him differently, even after all these years. He says that if he told them the reality of what had happened in Vietnam, they would not think he could be normal. Clark argues that the isolation began in combat, where the soldier became isolated from his own values, the values of his parents, and the values of his God. "Some still live in the woods." The impact of Vietnam on the later family is visible in these conversations.

For many veterans in this sample, friendships are also few and purposeful. Earl comments that "friendships now have meaning, they have substance...It's what I can coach and develop in that person...Hopefully I will receive something from them in return." Half of the respondents describe helping other veterans with problems, or helping men in Alcoholics Anonymous or other substance abuse programs. Frank now cuts others off like his brother cut him off-"squeeze their guts out" - and they are eventually grateful in recovery. He used his family experiences to move on and to help others. George, the only respondent to openly discuss his diagnosis of full-blown PTSD, got tired of watching veterans wait in line at the Department of Veterans Affairs office. He now volunteers at a community-based veteran service center and says that helping veterans helped his PTSD.

Most of these veterans described the influence of Vietnam on their emotional and social relationships in negative terms. A few described fairly normal households and family lives without significant problems. There did not seem to be anything exceptional about these few or about their experiences in Vietnam or later. However, Chuck described the warm welcome that he received from other veterans upon returning home with significant appreciation in his 
voice. Those who described early success with work seemed more settled overall; that success may reflect less severe PTSD symptoms to begin with. But typically, the veterans recalled themselves as husbands and fathers whose damaged emotions lived on and continued to stress or damage their families over time, both in specific instances of arguments, fights, or violence, and in broader terms by affecting the overall family atmosphere. For some, the economic stability of the family was threatened by ongoing trouble with employment as well. Forty years later, these veterans still acknowledge the permanent effect on their families.

\section{Discussion}

The goal of this analysis was to explore the meanings that Vietnam War combat veterans give to PTSD symptoms as they influence later family life. These lingering symptoms remain relevant because most veterans returned home to their primary families and went on to create families of their own. Five of the six diagnostic standards for PTSD guided a phenomenological analysis and interpretation of interviews with 10 infantry combat veterans. Each of the respondents described specific symptoms (re-experiencing, avoidance and numbing, arousal, and impaired social relationships) as they related to their Vietnam combat experience. Over time, these symptoms remained and served to shape family dynamics and function to the current day. This analysis offers a view of the veterans' interpretation of PTSD symptoms outside the scope of broad population rates and statistical significance, allowing for a richer examination of veterans' experiences within the family. It also represents an unprompted look at how veterans might discuss the impact of PTSD symptoms on families. Hopefully, findings from this study can spur on larger studies of the impact of PTSD symptoms on families over time, particularly in the face of new military contexts and veteran experiences.

One of the central efforts of the initial NVVRS (Kulka et al., 1990a) was to elicit lifetime exposure to trauma, i.e., not to assume that all PTSD would be a result of Vietnam. These interviews confirm this supposition, with some veterans describing how violent or dysfunctional family relationships before Vietnam had a larger influence than combat had on their post-combat adjustment and behavior. There is a fairly robust research literature already in place for the contemporary wars in Afghanistan and Iraq, one that focuses primarily on PTSD rates and symptoms (Jukupcak et al., 2007; Luxton, Skopp, \& Maguen, 2010; Ramchand et al., 2010) and treatment protocols (Chard, Schumm, McIlvain, Bailey, \& Parkinson, 2011; Garske, 2011; Riggs \& Sermanian, 2012). In one study only $23 \%$ to $40 \%$ of those who screened positively for a mental health problem sought help (Hoge et al., 2004). Those with positive scores for a mental health disorder were twice as likely to be concerned with the stigma attached to seeking help than those who scored negatively. Currently there is significant disagreement about the worst outcome of these symptoms, the suicide rates of veterans (Gibbons, Brown, \& Hur, 2012). Miller et al. (2009) describe no difference in suicide risk for middle-aged and elderly veterans, while Kaplan, Huguet, McFarland, \& Newsom (2007) suggest double the suicide risk between veterans and nonveterans. 
Large-scale research conducted shortly after the Vietnam War demonstrated that social support from wives or friends and living in a small city mitigated stress reactions (Egendorf et al, 1981). The 1990 NVVRS project concluded that despite continuing problems related to PTSD, the majority of veterans successfully reentered civilian life (Kulka et al., 1990a, 1990b). Decades later, families and friends are likely accustomed to PTSD symptoms, even if troublesome. One respondent, in the project that inspired this analysis, described the teasing he gets when he "hits the floor" at a loud sound (Kovach, 2007). This suggests that family and friends may have a sympathetic or amused response to some symptoms or, at the very least, have adjusted to symptom occurrence. However, emotional distancing, overly-controlling behavior, angry outbursts, physical violence, and substance abuse have catastrophic results for families and the work lives that stabilize them economically. Long-standing emotional turmoil in one member of a family, particularly a parent, can either damage family function and cohesion or fracture it altogether, with spouses and children as collateral damage. Adult children have the capacity to control what kind of relationship they have with their primary family as well, and long-term PTSD symptoms can shape those relationships with veteran parents. Some adult children may choose a tolerant or forgiving path, while others will turn away from the suffering they experienced as children, severing the relationship, never to return. Unfortunately, a third group may learn the behaviors of the angry, distant, controlling father and perpetuate these behaviors in their own families. Klika and Herrenkohl (2013) offer an overview of the literature on longitudinal studies of maltreated children and resilience.

As this Vietnam cohort ages and potentially needs more medical help and assistance with basic living, we need to be attuned to the presence of long-term PTSD symptoms. Consider a 70-year-old, male, heavy combat veteran who is hospitalized: now sleepless, disoriented, and in pain, with no control over his environment, who begins to experience nightmares or increased startling reactions at the pace of hospital functions. PTSD symptoms may have driven away the family and friends who could provide some structure or social interaction during the hospital stay. Or consider the 65-year-old father who can no longer live alone or who needs help with Medicare applications upon retirement, but whose relationships with a spouse, former spouse, or adult children have been damaged over decades by PTSD symptoms and finds that his only help can be found within the Veterans Affairs system. In an aging or end-of-life scenario, adults whose childhood home included a father with significant PTSD symptoms might be called upon for input on care options. Will they return the phone call from a doctor, an insurance company, or the hospice service? Many of these troubled family relationships become exposed with aging, illness, and end-of-life decisions.

Families suffer the consequences of combat in significant and long-term ways. Public policy should recognize that the shadow army of military families does not disappear when deployment or enlistment ends. Clinical application of the new VA/DOD guidelines suggest the importance of family involvement early on for assessment and treatment (Monson, Macdonald, \& Brown-Bowers, 2012; 
Nash \& Watson, 2012). Advances are forthcoming with new diagnostic criteria for PTSD (APA, 2013) and new assessment tools for measuring functional impairment related to PTSD (Rodriguez et al., 2012). These advances may help contemporary and future combat veterans but will not serve to repair damage already done to families of wars long past. Efforts to provide family support in cases of PTSD are also needed.

This project is limited by the recruitment pool, self-selection bias, and small size of the sample compared to large-scale, national studies. Interviews were of veterans themselves and not family members; different insights could be gained if future studies included interviews of family members as well as veterans. Care must be taken not to presume that all families of Vietnam War combat veterans have been maltreated or abused. While combat veterans of World War II, Korean War, and Vietnam War are nearly all male, recent wars have also seen combat exposure and injuries to more women, who would bring different perspectives to this research. PTSD criteria are also being refined over time. As an analytic strategy and attempt to bring clarity to the data, the researcher used the diagnostic schedule for PTSD as a conceptual framework for this phenomenological project. Re-ordering the themes to fit into the PTSD symptom outline should not be viewed as a facile way to understand the complexity of post-combat family life, however. Finally, veteran selfinterpretation of the connection between combat experiences, PTSD symptoms, and the effects on family life is not a substitute for the nuances and subtleties of full psychiatric evaluation and diagnosis.

The strength of this project lies in its currency. Many studies involve reanalysis of older data sets which do not take into account the changes and development of family structure. Implying both the advance of time and increased structural complexity, the later family is now extended by grown children and grandchildren, in-laws, step-children and step-families, perhaps former wives. Only three of the interview subjects had small children living at home: One had two young children with his second wife in addition to his adult children, one had a daughter and granddaughter living in his home, and the third had adopted six grandchildren. All others spoke of high-school-aged or grown children and grandchildren. There is a paucity of research that offers the voices and meaning that middle-aged and near-elderly veterans find in their PTSD symptoms across the years of family life. This project is different in that it reflects on PTSD symptoms as interpreted by the veterans and how those symptoms are visited on family members. Statistical analysis of rates of family adjustment and levels of impairment are critically important for policy decisions, but hearing the veterans' interpretations of those experiences leads to a richer understanding.

This phenomenological analysis examined the influence of Vietnam veterans' PTSD symptoms on their families. While the stereotype of the isolated, homeless, troubled Vietnam veteran is well-known in popular culture and has some evidence to defend it (Carlson, Garvert, Macia, Ruzek, \& Burling, 2013; Dail, 2000; Gamache, Rosenheck, \& Tessler, 2001; Rosenheck, Gallup, \& Leda, 1991), most Vietnam War veterans returned to get jobs, get married, and create 
families. Since they are no longer the young husbands and fathers of early postVietnam War, research should take into account the changes of family structure and function that occur over time and how or whether PTSD symptoms continue to affect later families. The voices of these veterans also offer insight into largescale quantitative PTSD research. Combat experiences and PTSD symptoms have lingered, both challenging and shaping these later families, who deserve our full attention.

\section{References}

Aldwin, C.M., Levenson, M.R.,, \& Spiro, A. (1994). Vulnerability and resilience to combat exposure: Can stress have lifelong effects? Psychology \& Aging, 9, 34-44.

American Psychiatric Association. (2000). Diagnostic and statistical manual of mental disorders ( ${ }^{\text {th }}$ ed. Revised). Washington, DC.

American Psychiatric Association. (2012). DSM-5 fact sheets: Posttraumatic stress disorder. Retrieved from http:www.psychiatry.org/practice/dsm/dsm5

American Psychiatric Association. (2013). Diagnostic and statistical manual of mental disorders: DSM-5. (5 ${ }^{\text {th }}$ ed.). Washington, DC.

Barret, D.H., Resnick, H.S., Foy, D.W., Dansky, B.S., Flanders, W.D., \& Stroup, N.E. (1996). Combat exposure and adult psychosocial adjustment among U.S. Army veterans serving in Vietnam, 1965-1971. Journal of Abnormal Psychology, 105, 575-581.

Brady, P.S. (2011, March/April). Not dead yet: Mortality rates among Vietnam veterans. The VVA Veteran. Retrieved from http://digitaledition.qwinc.com/display_article.php?id=675095

Carlson, E. B., Garvert, D. W., Macia, K. S., Ruzek, J. I., \& Burling, T. A. (2013). Traumatic stressor exposure and post-traumatic symptoms in homeless veterans. Military Medicine, 178, 970-973.

Centers for Disease Control Vietnam Experience Study. (1988). Health status of Vietnam veterans: Psychosocial characteristics. Journal of the American Medical Association, 259, 2701-2707.

Chard, K. M., Schumm, J. A., McIlvain, S. M., Bailey, G. W., \& Parkinson, R. B. (2011). Exploring the efficacy of a residential treatment program incorporating cognitive processing therapy-cognitive for veterans with PTSD and traumatic brain injury. Journal of Traumatic Stress, 24, 347351. 
Creswell, J.W. (2003). Research design: qualitative, quantitative, and mixed methods approaches $\left(2^{\text {nd }}\right.$ ed.). Thousand Oaks, CA: Sage.

Committee to Review the Health Effects in Vietnam Veterans of Exposure to Herbicides, Institute of Medicine. (1994). Veterans and Agent Orange: Health effects of herbicides used in Vietnam. Washington, DC: National Academies Press. Retrieved from http://www.nap.edu/openbook.php?isbn=0309048877

Dansby, V.S., \& Marinelli, R.P. (1999). Adolescent children of Vietnam combat veteran fathers: A population at risk. Journal of Adolescence, 22, 329340 .

Dail, P.W. (2000). Introduction to the symposium on homelessness. Policy Studies Journal, 28, 331-337.

Dohrenwend, B. P., Turner J. B., Turse, N. A., Adams, B. G, Koenen, K. C., \& Marshall, R. (2006). The psychological risks of Vietnam for U.S. veterans: A revisit with new data and methods. Science, 313, 979-982.

Egendorf, A., Kadushin, C., Laufer, R.S., Rothbert, G., \& Sloan, L. (1981). Legacies of Vietnam: Comparative adjustment of veterans and their peers. Washington, DC: U.S. Government Printing Office.

Elder, G.H., \& Clipp, E.C. (1989). Combat experience and emotional health: Impairment and resilience in later life. Journal of Personality, 57, 311341.

Gamache, G., Rosenheck, R., \& Tessler, R. (2001). The proportion of veterans among homeless men: A decade later. Social Psychiatry \& Psychiatric Epidemiology, 36, 481-485.

Garske, G. G. (2011). Military-related PTSD: A focus on the symptomatology and treatment approaches. Journal of Rehabilitation, 77 (4), 31-36.

Gibbons, R.D., Brown, C.H., \& Hur, K. (2012). Is the rate of suicide among veterans elevated? [Editorial]. American Journal of Public Health, 102, S17-S19.

Gibbs, D.A., Clinton-Sherrod, A.M., \& Johnson, R.E. (2012). Interpersonal conflict and referrals to counseling among married soldiers following return from deployment. Military Medicine, 177, 1178-1183.

Gimbel, C., \& Booth, A. (1996). Who fought in Vietnam? Social Forces, 74, 1137-1157. 
Hendrix, C. C., \& Anelli, L. M. ( 1993). Impact of Vietnam War service on veterans' perceptions of family life. Family Relations, 42, 87-92.

Hendrix, C.C., Erdmann, M.A., \& Briggs, K. (1998). Impact of Vietnam veterans' arousal and avoidance on spouses' perceptions of family life. American Journal of Family Therapy, 26 (2), 115-128.

Hoge, C.W., Castro, C.A., Messer, S.C., McGurk, D., Cotting, D.I., \& Koffman, R.L. (2004). Combat duty in Iraq and Afghanistan, mental health problems, and barriers to care. The New England Journal of Medicine, $351,13-22$.

Johnson, D.R., Lubin, H., Rosenheck, R., Fontana, A., Southwick, S., \& Charney, D. (1997). The impact of the homecoming reception on the development of posttraumatic stress disorder: The West Haven Homecoming Stress Scale (WHHSS) [Electronic version]. Journal of Traumatic Stress, 10, 259-276.

Jukupcak, M., Conybeare, D., Phelps, L., Hunt, S., Holmes, H.A., Felker, B.,...McFall, M.E. (2007). Anger, hostility, and aggressions among Iraq and Afghanistan war veterans reporting PTSD and subthreshold PTSD. Journal of Traumatic Stress, 20, 945-954.

Kaplan, M.S., Huguet, N., McFarland, B.H. \& Newsom, J.T. (2007). Suicide among male veterans: A prospective population-based study. Journal of Epidemiology \& Community Health, 61 (7), 619-624.

Kaylor, J.A., King, D.W., \& King, L.A. (1987). Psychological effects of military service in Vietnam: A meta-analysis. Psychological Bulletin, 102, 257271.

King, D.W. \& King, L.A. (1991). Validity issues in research on Vietnam veteran adjustment. Psychological Bulletin, 109, 107-124.

Klika, J. B. \& Herrenkohl, T. I. (2013). A review of developmental research on resilience in maltreated children. Trauma Violence Abuse, 14, 222-234.

Koenen, K.C., Stellman, S.D., Sommer, J.F., Jr., \& Stellman, J.M. (2008). Persisting posttraumatic stress disorder symptoms and their relationship to functioning in Vietnam veterans: A 14-year follow-up. Journal of Traumatic Stress, 21 (1), 49-57.

Kovach, T. (2006). The constant companion: The integration of Vietnam War combat experiences into later adulthood (Doctoral dissertation). Dissertation Abstracts International. (AAT 3218286) 
Kovach, T. (2007, October). A folding chair falls on the church basement floor: PTSD in the community 40 years after Vietnam. Paper presented at the meeting of the Association for Applied and Clinical Sociology, Ypsilanti, MI.

Kulka, R.A., Schlenger, W.E., Fairbank, J.A., Hough, R.L., Jordan, B.K., Marmar, C.R., et al. (1990a). The national Vietnam veterans readjustment study: Table of findings and appendices. New York: Brunner/Mazel.

Kulka, R.A., Schlenger, W.E., Fairbank, J.A., Hough, R.L., Jordan, B.K., Marmar, C.R., et al. (1990b). Trauma and the Vietnam War generation: Report of findings from the National Vietnam Veterans Readjustment Study. New York: Brunner/Mazel.

Laufer, R.S., Gallops, M.S., \& Frey-Wouters, E. (1984). War stress and trauma: The Vietnam experience. Journal of Health and Social Behavior, 25, 6585 .

Linderman, G.F. (1997). The world within war: America's combat experience in World War II. New York: Free Press.

Luxton, D. D, Skopp, N. A., \& Maguen, S. (2010). Gender differences in depression and PTSD symptoms following combat exposure. Depression \& Anxiety, 27, 1027-1033.

Management of Post-Traumatic Stress Working Group. (2010). VA/DOD clinical practice guideline for management of post-traumatic stress, Version 2.0. Washington, DC: Department of Veterans Affairs, Department of Defense. Retrieved from http://www.healthquality.va.gov/ptsd/cpg_PTSD-Full-201011612.pdf

Martz, E., Bodner, T., \& Livneh, H. (2009). Coping as a moderator of disability and psychosocial adaptation among Vietnam theater veterans. Journal of Clinical Psychology, 65, 94-112.

Miller, M., Barber, C., Azrael, D., Calle, E.E., Lawler, E., \& Mukamal, K.J. (2009). Suicide among US veterans: A prospective study of 500,000 middle-aged and elderly men. American Journal of Epidemiology, 170, 494-500.

Monson, C.M., Macdonald, A., \& Brown-Bowers, A. (2012). Couple/family therapy for posttraumatic stress disorder: Review to facilitate interpretation of VA/DOD Clinical Practice Guideline. Journal of Rehabilitation Research \& Development, 49, 717-728.

Nash, W.P., \& Watson, P.J. (2012). Review of VA/DOD Clinical Practice 
Guideline on management of acute stress and interventions to prevent posttraumatic stress disorder. Journal of Rehabilitation Research \& Development, 49, 637-648.

Nelson, B.S., \& Wright, D.W. (1996). Understanding and treating post-traumatic stress disorder symptoms in female partners of veterans with PTSD. Journal of Marital and Family Therapy, 22, 455-467.

Ramchand, R., Schell, T. L., Karney, B. R,, Osilla, K. C., Burns, R. M., \& Caldarone, L. B. (2010). Disparate prevalence estimates of PTSD among service members who served in Iraq and Afghanistan: Possible explanations. Journal of Traumatic Stress, 23, 59-68.

Riggs, D. S., \& Sermanian, D. (2012). Prevention and care of combat-related PTSD: Directions for future explorations. Military Medicine, 2012 Aug., 14-20.

Rodriguez, P., Holowka, D.W., \& Marx, B.P. (2012). Assessment of posttraumatic stress disorder-related functional impairment: A review. Journal of Rehabilitation Research \& Development, 49, 649-665.

Rosenheck, R., Gallup P., \& Leda, C. A. (1991). Vietnam era and Vietnam combat veterans among the homeless. American Journal of Public Health, 81, 643-646.

Sharkansky, E.J, King, D.W., King, L.A, Wolfe, J., Erickson, D.J., \& Stokes, L.R. (2000). Coping with Gulf War combat stress: Mediating and moderating effects. Journal of Abnormal Psychology, 109, 188-197.

Shay, J. (1994). Achilles in Vietnam: Combat trauma and the undoing of character. New York: Atheneum.

Silverstein, R. (1996). Combat-related trauma as measured by ego developmental indices of defenses and identity achievement. Journal of Genetic Psychology, 157, 169-179.

Street, A.E., King, L.A, \& King, D.A. (2003). The associations among maleperpetrated partner violence, wives' psychological distress and children's behavior problems: A structural equation modeling analysis. Journal of Comparative Family Studies, 34, 23-40.

U.S. Census Bureau. (2011). Period of military service for civilian veterans 18 years and over: 2011 American Community Survey 1-year estimates. Retrieved from http://factfinder2.census.gov/rest/dnldController/deliver?_ts=3870562084 61 
Van Winkle, E.P., \& Safer, M.A. (2011). Killing versus witnessing in combat trauma and reports of PTSD symptoms and domestic violence. Journal of Traumatic Stress, 24, 107-110.

Watkins, L., Taft, C., Hebenstreit, C., King, L., \& King, D. (2008). Predictors of child behavior problems among children of female Vietnam veterans. Journal of Family Violence, 23, 135-140.

Williams, J. E., Johnson, A. M., Heiss, G., \& Rose, K. M. (2010). Association between exposure to combat-related stress and psychological health in aging men: The Atherosclerosis Risk in Communities (ARIC) Study. Journal of Traumatic Stress, 23, 358-366.

Zatzick, D.F., Marmar, C.R., \& Weiss, D.S. (1997). Posttraumatic stress disorder and functioning and quality of life outcomes in a nationally representative sample of male Vietnam veterans. American Journal of Psychiatry, 157, 1690-1695. 